\title{
PSYCHOLOGICAL AND PEDAGOGICAL DETERMINANTS OF THE STUDENTS' HEALTHY LIFESTYLE FORMATION BY MEANS OF HEALTH AND FITNESS ACTIVITIES
}

DOI: 10.36740/WLek202105105

\author{
Grygoriy P. Griban ${ }^{1}$, Mykhailo S. Myroshnychenko ${ }^{2}$, Pavlo P. Tkachenko ${ }^{3}$, Valerii P. Krasnov ${ }^{4}$, Roman P. Karpiuk ${ }^{5}$, \\ Olha B. Mekhed ${ }^{6}$, Volodymyr M. Shyyan ${ }^{7}$ \\ 'ZHYTOMYR IVAN FRANKO STATE UNIVERSITY, ZHYTOMYR, UKRAINE \\ 2NATIONAL MEDICAL UNIVERSITY, KHARKIV, UKRAINE \\ 3POLISSIA NATIONAL UNIVERSITY, ZHYTOMYR, UKRAINE \\ ${ }^{4}$ NATIONAL UNIVERSITY OF LIFE AND ENVIRONMENTAL SCIENCES OF UKRAINE, KYIV, UKRAINE \\ ${ }^{5}$ ACADEMY OF RECREATIONAL TECHNOLOGIES AND LAW, LUTSK, UKRAINE \\ "T.H. SHEVCHENKO NATIONAL UNIVERSITY"CHERNIHIV COLEHIUM", CHERNIHIV, UKRAINE \\ 'PRYDNIPROVSKA STATE ACADEMY OF CIVIL ENGINEERING AND ARCHITECTURE, DNIPRO, UKRAINE
}

\begin{abstract}
The aim: Is to investigate the psychological and pedagogical determinants of the students' healthy lifestyle formation by means of health and fitness activities.

Materials and methods: The study involved 882 students between the ages of 17 and 23. An analysis of the students' health dynamics during the period of study determined their motivational and value-based attitude to a healthy lifestyle, the level of health competence and the desire of students to implement it in future professional activities, studied the attitude of students to their own health

Results: It was found that during two years of study, the health of students had significantly deteriorated. The number of sick students increased to $34.8 \%$ among males and to $31.9 \%$ among females. It was found that only $12.3 \%$ of male students and $10.6 \%$ of female ones had a high level of motivation for a healthy lifestyle.

Conclusions: It was determined that students were aware of the importance of a high level of health to ensure the effectiveness of vital activity (more than $50 \%$ of students realized the value of health in the system of life values), but the vast majority did nothing to maintain it. Most students did not have the knowledge, skills, and abilities to use health technologies during studying and leisure.
\end{abstract}

KEY WORDS: health, healthy lifestyle, physical education, students

Wiad Lek. 2021;74(5):1074-1078

\section{INTRODUCTION}

The reasons for the health deterioration of students include insufficient attention to the issues of physical education in families, secondary schools, vocational, and higher education institutions (HEI). The current system of physical education in Ukraine does not meet the natural biological needs of young students for physical activity. As a result, the majority of the HEI students in Ukraine (over $75 \%$ ) have low and below the middle levels of somatic health [1-5]. More than $50 \%$ of first-year students (both male and female) have various disorders in physical development, musculoskeletal system, and various chronic diseases and disorders of the body's functional systems, etc. [6-10].

One of the most important tasks of the system of physical education in the HEI of Ukraine is to strengthen the health and physical fitness of students, promote mastery of skills and abilities to use the means of health and fitness activities in everyday life in order to maintain high performance, healthy lifestyle, physical fitness, and recovery of the organism from the negative effects of various environmental factors [11-15].

\section{THE AIM}

The aim of this study is to investigate the psychological and pedagogical determinants of the students' formation of a healthy lifestyle by means of health and fitness activities.

\section{MATERIALS AND METHODS}

The research was conducted at Polissia National University (PNU) and Zhytomyr Ivan Franko State University (ZSU) in 2018-2020. 882 students (385 males and 497 females) of different specialties between the ages of 17 and 23 were examined. To assess the formation state of the HEI students' healthy lifestyle during their study period, the dynamics of the health level of the students of PNU and ZSU during the 
Table I. The distribution of students by health status at the beginning of the study $(2018, \mathrm{n}=882, \%)$

\begin{tabular}{ccccc}
\hline Higher education institution & Gender & The main group & The special group & Exempted from physical activity \\
\hline \multirow{2}{*}{ ZSU } & male $(n=138)$ & 81.2 & 16.6 & 2.2 \\
\cline { 2 - 5 } & female $(n=273)$ & 78.4 & 18.7 & 2.9 \\
\hline \multirow{2}{*}{ PNU } & male $(n=247)$ & 84.2 & 14.2 & 1.6 \\
\cline { 2 - 5 } & female $(n=224)$ & 81.7 & 16.5 & 1.8 \\
\hline
\end{tabular}

Table II. The dynamics of students' health during two years of study (2018-2020, $n=882, \%)$

\begin{tabular}{cccccc}
\hline \multirow{2}{*}{$\begin{array}{c}\text { Higher education } \\
\text { institution }\end{array}$} & Gender & \multicolumn{2}{c}{ Beginning of the $\mathbf{2 0 1 8}$ academic year } & \multicolumn{3}{c}{ The end of the $\mathbf{2 0 2 0}$ academic year } \\
\cline { 3 - 6 } & & \multicolumn{3}{c}{ Healthy } \\
\hline \multirow{2}{*}{ ZSU } & male $(\mathrm{n}=138)$ & 81.2 & 18.8 & 68.1 & 31.9 \\
\cline { 2 - 6 } & female $(\mathrm{n}=273)$ & 78.4 & 21.6 & 65.2 & 34.8 \\
\hline \multirow{2}{*}{ PNU } & male $(\mathrm{n}=247)$ & 84.2 & 15.8 & 74.5 & 25.5 \\
\cline { 2 - 6 } & female $(\mathrm{n}=224)$ & 81.7 & 18.3 & 73.7 & 26.3 \\
\hline
\end{tabular}

study period was analyzed, the level of their motivational and value-based attitude to a healthy lifestyle and the level of health-promoting competence were determined, the relationship of students to their own health was investigated (realization by students of the value of their own health in the system of life values), and the desire of students to realize their health-preserving competence in life and professional activity was clarified. Medical examinations were performed by doctors of medical centers of these HEI. The study of the motivational and value-based attitude of students to a healthy lifestyle, the formation of health-preserving competence and the desire to realize it in future professional activities, students' attitudes to their own health was conducted on the original questionnaires complying with all necessary requirements for sociological research.

Research methods: the analysis and generalization of literary sources, the study and analysis of the students' medical records, pedagogical observation, questionnaires, the methods of mathematical statistics.

The study was approved by the ethics committee of the Polissia National University (PNU), which determined that the general ethical rules of humane treatment of patients were observed when working with patients in accordance with the requirements of the Tokyo Declaration of the World Medical Association and the International Recommendations of the Helsinki Declaration of Human Rights.

\section{RESULTS}

To assess the state of healthy lifestyle formation of the HEI students during the studying, the dynamics of the health level of the students of PNU and ZSU were analyzed during the study period, the level of their motivational and value-based attitude to a healthy lifestyle and the level of health-promoting competence were determined, the students' attitude to their own health (realization of the value of one's own health in the system of life values by students) was investigated and the desire of students to realize their health-preserving competence in everyday life and professional activity was clarified.
The results of the study show that at the beginning of the 2018 academic year, $81.2 \%$ of the male students and $78.4 \%$ of the female students of ZSU and 84.2 and $81.7 \%$ of the students of PNU, respectively, had a good level of health, were assigned to the main medical group by health status and could fulfill the program requirements for physical education and state tests, assessing physical fitness (Table I). The special medical group included 14.2-18.7 \% students and the number of students with significant health or special needs identified accounted for 1.6 to $2.9 \%$.

A comparative analysis of the distribution of students by medical groups over the last two years of the study confirmed a sharp deterioration in their health. At the beginning of the 2018 academic year, $81.2 \%$ of male students and $78.4 \%$ of female students with a good level of health who belonged to the main educational department were determined at ZSU. During the two academic years, $68.1 \%$ of males and $65.2 \%$ of females with good health remained in this group, and the number of students assigned to a special medical group increased significantly (Table II). The health indicators remained somewhat better at PNU. It was found that in two years of the study when physical education classes were reduced to one hour a week, students' health deteriorated significantly. The number of sick students, who belong to a special medical group, increased to $31.9 \%$ for females, and $34.8 \%$ for females at ZSU, and to 25.5 and $26.3 \%$ respectively at PNU. Among them, many students had chronic diseases, disabilities, and were generally exempt from physical activity.

The value-based orientations of a student influence one's purposefulness, vital activity, or vice versa passivity. The developed system of value-based orientations of students motivates them to health-improving actions, following a healthy way of life. Involving students in extracurricular sports activities and the opportunity to continue them in the process of compulsory physical education classes in sports-oriented groups act as a link between educational and extracurricular activities and increase the amount of physical activity of students. The implementation of this recommendation in the lives of students, of course, would 
bring positive results, but there are a number of problems related to the material and technical resources, teaching staff, broad interests of students, which could not be implemented at all at this stage because of the reduction of teachers and hours devoted to the process of physical education and free work of various groups at universities.

The obtained results made it possible to state that among ZSU students only $12.3 \%$ of males had a high level of motivation for a healthy lifestyle, $29.7 \%$ - medium, and the vast majority - low (58.0\%), which, accordingly, had a negative impact on students' health. The female students had even less motivation to follow the norms of a healthy lifestyle, namely: the number of students with a high level accounted for $10.6 \%$, a medium level - $30 \%$, and a low level $-59.4 \%$. The motivation of PNU students to follow a healthy lifestyle was not significantly better, in particular, $14.2 \%$ of males and $9.8 \%$ of females had a high level of motivation, $35.2 \%$ and $33.9 \%$ - medium, and $50.6 \%$ and $56.3 \%$ - low (Table III).

The students' activities for the implementation of health-promoting education technologies should be based on the principles of value-based orientation to health and a healthy lifestyle, integrativeness, humanism, individualization, continuity, and consistency. Thus, physical culture as a type of culture is a specific process and result of human activity, a means, and method of physical improvement for the performance of social functions.

Youth health problems are actualized in the face of adverse social, environmental, and economic factors. The idea of creating, substantiating, and implementing the methods of forming health-promoting competencies of students during the study at HEI is a way to solve this problem. At the same time, a very important factor in the formation of health-promoting competencies of future professionals is health and fitness activities at HEI, the ability of students to systematically engage in physical activities and various sports. The results of the research showed that in all studied groups, the level of health-promoting competencies of 50.7-62.3\% of students was low, i.e. most students did not have the knowledge, skills, and abilities to use health-preserving technologies during training, recreation, leisure, etc. (Table IV).

A study of students' attitude to their own health showed that students understood its importance because only $2.2 \%$ of ZSU students could not assess the importance of good health for life. Similar data were obtained from the students of PNU (Table V). It can be stated that the thesis formed in the literature and normative documents on the devaluation of health in the social consciousness is not sufficiently justified and is, therefore, premature and unreasonable. The students understood the importance of good health very well, but the vast majority did nothing to maintain it. The obtained data give good grounds to claim that the "dominant core" in the structure of students' life values is their own health.

The analysis of the study results of the health-preserving competence of future professionals showed that only 10.3$15.8 \%$ of students had a high desire to implement their knowledge, skills, and abilities in their future professional activities. The students in this group employed the concepts of "competence", "health", "health promotion", "health-promoting competence", "health-promoting technology", and could name the components of health. From $46.9 \%$ to $57.1 \%$ of students, who stated that they did not have enough knowledge to carry out health activities, had an average desire. From $31.2 \%$ to $37.3 \%$ of students were not interested in their profession and did not care about mastering professional competencies and could define the concepts only with the help of a teacher, although they claimed that they had enough knowledge about health preservation to implement them in their own lives (Table VI). At the same time, low-prepared students did not show much desire to change the situation for better mastery of health and fitness competencies.

\section{DISCUSSION}

One of the priorities of the education system is to teach the individual to have a responsible attitude to both one's own health and the health of others. The formation of health culture, healthy lifestyle skills, and the values of one's own health should begin at early school age. It is an open secret that today, a significant number of children have health problems and poor physical fitness, which is associated with huge study loads of primary school children, disrupted alteration of work and rest, reduced physical activity of students [16, 17]. Instead, the analysis of scientific sources $[18,19,20]$ shows that domestic pedagogy does not pay due attention to the theoretical and methodical principles of forming the readiness of future school teachers to organize the lives of students, teaching and education based on health-preserving methods, the formation of the students' health-promoting skills and abilities, which causes some difficulties in later life. Thus, this indicates a number of contradictions that require an urgent solution, namely between: the needs for the realization of the society's goal in terms of educating a healthy generation and the real state of theoretical and methodical substantiation of the preparation of future professionals for the performance of health-preserving activities; the relevance of applying the special methods of preserving and promoting health in the educational process and their insufficient development and efficiency; a low level of health of the school and university students and insufficient preparation of teachers for preserving and strengthening the health of students; a growing awareness of students of the need to gain knowledge to strengthen and preserve their health and the lack of the necessary methodological support for the formation of health-promoting skills and abilities at modern pedagogical higher educational institutions; the development level of modern health-preserving methods and their insufficient practical implementation in the educational process at HEI $[3,4,15,16,19,20]$.

The practice of health preservation is presented as a valuable, permanent, and competence-based activity. An important component of an individual's health is physical health. We believe that it is impossible to carry out pro- 
Table III. The motivational and value-based attitude level of students to healthy lifestyle $(2020, n=882, \%)$

\begin{tabular}{ccccc}
\hline \multirow{2}{*}{$\begin{array}{c}\text { Higher education } \\
\text { institution }\end{array}$} & Gender & \multicolumn{3}{c}{ Motivational and value-based level } \\
\cline { 2 - 5 } ZSU & male $(\mathrm{n}=138)$ & High & Medium & 58.0 \\
\cline { 2 - 5 } & female $(\mathrm{n}=273)$ & 12.3 & 30.0 & 59.4 \\
\hline \multirow{2}{*}{ PNU } & male $(\mathrm{n}=247)$ & 14.2 & 35.2 & 50.6 \\
\cline { 2 - 5 } & female $(\mathrm{n}=224)$ & 9.8 & 33.9 & 56.3 \\
\hline
\end{tabular}

Table IV. The level of health-preserving competence of students $(2020, \mathrm{n}=882, \%)$

\begin{tabular}{ccccc}
\hline \multirow{2}{*}{$\begin{array}{c}\text { Higher education } \\
\text { institution }\end{array}$} & Gender & \multicolumn{3}{c}{ Health-preserving competence } \\
\cline { 3 - 5 } ZSU & male $(\mathrm{n}=138)$ & 10.9 & Medium & 30.4 \\
\cline { 2 - 5 } & female $(\mathrm{n}=273)$ & 8.8 & 28.9 & 62.3 \\
\hline \multirow{2}{*}{ PNU } & male $(\mathrm{n}=247)$ & 12.6 & 36.0 & 51.4 \\
\cline { 2 - 5 } & female $(\mathrm{n}=224)$ & 8.9 & 34.8 & 56.3 \\
\hline
\end{tabular}

Table V. Realization of the value of one's own health in the system of life values by students ( $2020, n=882, \%)$

\begin{tabular}{ccccc}
\hline \multirow{2}{*}{$\begin{array}{c}\text { Higher education } \\
\text { institution }\end{array}$} & Gender & \multicolumn{3}{c}{ The value of one's own health } \\
\cline { 2 - 5 } ZSU & male $(\mathrm{n}=138)$ & High & Medium & 38.4 \\
\hline \multirow{2}{*}{ PNU } & female $(\mathrm{n}=273)$ & 59.4 & 49.1 & - \\
\hline & male $(\mathrm{n}=247)$ & 53.0 & 45.0 & 2.0 \\
\hline & female $(\mathrm{n}=224)$ & 33.9 & 65.2 & 0.9 \\
\hline
\end{tabular}

Table VI. The desire of students to realize their health-preserving competence in everyday life and professional activity $(2020, n=882, \%)$

\begin{tabular}{ccccc}
\hline \multirow{2}{*}{$\begin{array}{c}\text { Higher education } \\
\text { institution }\end{array}$} & Gender & \multicolumn{2}{c}{ The desire to realize health-preserving competence } \\
\cline { 2 - 5 } & & High & Medium & Low \\
\hline \multirow{2}{*}{ ZSU } & male $(\mathrm{n}=138)$ & 13.8 & 55.0 & 31.2 \\
\cline { 2 - 5 } & female $(\mathrm{n}=273)$ & 10.3 & 57.1 & 32.6 \\
\hline \multirow{2}{*}{ PNU } & male $(\mathrm{n}=247)$ & 15.8 & 46.9 & 37.3 \\
\cline { 2 - 5 } & female $(\mathrm{n}=224)$ & 11.2 & 57.1 & 31.7 \\
\hline
\end{tabular}

fessional activities, especially pedagogical ones, without physical health because the educational process should be aimed at developing and improving the physical and motor qualities of students. This type of activity is especially important in primary school.

\section{CONCLUSIONS}

1. It was found that students' health deteriorated significantly during the two years of studying at HEI. The number of students who were assigned to the main educational department at the beginning of the study decreased by $13.1 \%$ among males and by $13.2 \%$ among females. The number of sick students increased to $34.8 \%$ among males and to $31.9 \%$ among females. It was defined that only $12.3 \%$ of male students and $10.6 \%$ of female students had a high level of motivation for a healthy lifestyle. The level of health-preserving competencies of 50.7-62.3\% of surveyed students was low. The majority of students did not have the knowledge, skills, and abilities to use health-promoting technologies during study, recreation, and leisure. Only 10.3-15.8\% of students had a high desire to implement their knowledge, skills, and abilities in future professional activities.

2. The physical health of a future specialist is ensured by a positive attitude to health as a universal value, sufficient physical activity, nutrition, compliance with sanitary and hygienic skills, as well as the realization of the need for sports, health and fitness activities that will promote not only the formation of health-preserving skills and abilities and physical health strengthening but also the acquisition of skills to organize the corresponding health-preserving activity in the further professional activity.

3. It was established that students understood the importance of a high level of health to ensure the effectiveness of life (more than $50 \%$ of students realized the value of health in the system of life values), but the vast majority did nothing to maintain it. 


\section{REFERENCES}

1. Mozolev 0., Khmara M., Shorobura I. et al. Comparative analysis of the effectiveness of Polish and Ukrainian basic training programs in physical education for 9-10-year-old pupils. Universal Journal of Educational Research. 2019; 7(11): 2345-2351. doi: 10.13189/ujer.2019.071112.

2. Gruzieva T., Galiienko L., Pelo I. et al. Health and lifestyle of students' youth: status, problems and ways of solution. Wiad Lek. 2018; 71(9): 1753-1758.

3. Griban G., Lyakhova N., Tymoshenko 0. Current state of students' health and its improvement in the process of physical education. Wiad. Lek. 2020; 73(7), 1438-1447. doi: 10.36740/WLek202007124.

4. Prontenko K., Griban G., Dovgan N. et al. Students' health and its interrelation with physical fitness level. Sport Mont. 2019; 17(3): 41-46. doi 10.26773/smj.191018.

5. Makarov S., Stoyan N., Serheta I., Taran 0., Dyakova 0. Peculiarities of the interaction of the indicators of psychophysiological adaptation of modern students in the context of the effective monitoring of individual health of young women and young men. Wiad. Lek. 2019; 72 (5a): 1053-1058.

6. Prontenko K., Griban G., Bloshchynskyi I. et al. Improvement of students' morpho-functional development and health in the process of sport-oriented physical education. Wiad Lek. 2020; 73(1): 161-168. doi: 10.36740/WLek202001131.

7. Prysiazhniuk S., Tolubko V., Oleniev D. et al. The influence of physical activities on biological age parameters of the first-year female students from the special medical department. Journal of Physical Education and Sport. 2018; 18(2): 561-564. doi:10.7752/jpes.2018.02081.

8. Prontenko K., Griban G., Prontenko V. et al. Health improvement of cadets from higher military educational institutions during kettlebell lifting activities. Journal of Physical Education and Sport. 2018; 18(1): 298-303. doi: 10.7752/jpes.2018.01040.

9. Griban G., Prontenko K., Zhamardiy V. et al. Professional stages of a physical education teacher as determined using fitness technologies. Journal of Physical Education and Sport. 2018; 18(2): 565-569. doi:10.7752/jpes.2018.02082.

10. Prontenko K., Griban G., Aloshyna A. et al. The physical development and functional state as the important components of the students' health. Wiad. Lek. 2019; 72(12a): 2348-2353. doi: 10.36740/WLek201912115.

11. Mozolev 0., Bloshchynsky I., Alieksieiev 0. et al. Influence of modern fitness technologies on the state of health and development of motor abilities of 17-19-year-old female students. Journal of Physical Education and Sport. 2019; 19(3): 917-924. doi:10.7752/jpes.2019. s3132.

12. Plisko V., Doroshenko T., Minenok A. et al. Informational indicators of functional capacities of the body for teaching cadets from higher military educational institutions power types of sports. Journal of Physical Education and Sport. 2018;2: 1050-1054. doi: 10.7752/jpes.2018.52156.

13. Danylenko H. M., Sotnikova-Meleshkina Zh. V., Smiianov V. A. The impact of an educational institution on development of healthy lifestyle skills for prevention of obesity in adolescents. Wiad. Lek. 2020; 73(5): 978982. doi: 10.36740/WLek202005126.

14. Prontenko K., Bloshchynskyi I., Griban, G. et al. Formation of readiness of future physical culture teachers for professional activity. Universal Journal of Educational Research. 2019; 7(9): 1860-1868. doi: 10.13189/ ujer.2019.070903.
15. Griban G., Tymoshenko 0., Arefiev V. et al. The role of physical education in improving the health status of students of special medical groups. Wiad. Lek. 2020; 73 (3): 534-540. doi: 10.36740/WLek202003125.

16. Griban G., Kobernyk 0., Terentieva N. et al. Formation of health and fitness competencies of students in the process of physical education. Sport Mont. 2020; 18(3): 73-78. doi: 10.26773/smj.201008.

17. Zhamardiy V., Shkola 0., Okhrimenko I. et al. Checking of the methodical system efficiency of fitness technologies application in students' physical education. Wiad Lek. 2020; 73 (2): 332-341. doi: 10.36740/ WLek202002125.

18. Griban G., Yavorska T., Tkachenko P. et al. Motor activity as the basis of a healthy lifestyle of student youth. Wiad. Lek. 2020; 73(6): 1199-1206. doi: 10.36740/WLek202006123.

19. Vilenskiy M. Ya. Sotsialno-psihologicheskie determinantyi formirovaniya zdorovogo obraza zhizni [Socio-psychological determinants of a healthy lifestyle]. Teoriya i praktika fizicheskoy kulturyi. 1994; 9: 9-11. (in Russian).

20. Apanasenko G., Dolzhenko L. Rivenj zdorov'ja i fiziologhichni rezervy orghanizmu. [The level of health and physiological reserves of the organism]. Teorija i metodyka fizychnogho vykhovannja i sportu. 2007; 1: 17-21. (in Ukrainian).

\section{ORCID and contibutionship:}

Grygoriy P. Griban: 0000-0002-9049-1485 ${ }^{A, F}$

Mykhailo S. Myroshnychenko: 0000-0002-6920-8374 ${ }^{A, E}$

Pavlo P. Tkachenko: 0000-0003-4407-8611 $1^{B, D}$

Valerii P. Krasnov: 0000-0002-5758-6909C,D

Roman P. Karpiuk: 0000-0003-0271-9206 ${ }^{B, D}$

Olha B. Mekhed: 0000-0001-9485-9139FE

Volodymyr M. Shyyan: 0000-0002-9438-3270,F

\section{Conflict of interest:}

The Authors declare no conflict of interest.

\section{CORRESPONDING AUTHOR Grygoriy P. Griban}

Zhytomyr Ivan Franko State University

40 Velyka Berdychivska St., 10002 Zhytomyr, Ukraine

tel: +380973341092

e- mail: gribang@ukr.net

Received: 11.11 .2020

Accepted: 29.03 .2021

A - Work concept and design, B - Data collection and analysis, C - Responsibility for statistical analysis, D-Writing the article, $\mathbf{E}$-Critical review, $\mathbf{F}$ - Final approval of the article 